\title{
Isolation and Characterization of Halothermothrix orenii gen. nov., sp. nov., a Halophilic, Thermophilic, Fermentative, Strictly Anaerobic Bacterium
}

\author{
J.-L. CAYOL, ${ }^{1}$ B. OLLIVIER, ${ }^{1 *}$ B. K. C. PATEL, ${ }^{2}$ G. PRENSIER,${ }^{3}$ J. GUEZENNEC ${ }^{4}$ AND J.-L. GARCIA ${ }^{1}$ \\ Laboratoire de Microbiologie, ORSTOM, Université de Provence, 13331 Marseille cedex $3,{ }^{1}$ Laboratoire de \\ Microbiologie, Université Blaise Pascal, 63177 Aubière cedex, ${ }^{3}$ and Laboratoire de Chimie et Corrosion \\ Marine, IFREMER, 29273 Brest cedex, ${ }^{4}$ France, and Faculty of Science and Technology, \\ Griffith University, Brisbane, Queensland 4111, Australia ${ }^{2}$
}

\begin{abstract}
The occurrence of thermophilic, halophilic anaerobic bacteria in the sediment of a Tunisian salted lake was tested in samples collected at $20-\mathrm{cm}$ intervals down to a depth of $1.20 \mathrm{~m}$. A long rod, present only in the 40 to $60-\mathrm{cm}$ layer, was isolated at $60^{\circ} \mathrm{C}$ in a medium containing $100 \mathrm{~g}$ of $\mathrm{NaCl}$ per liter and designated strain $\mathrm{H168}$. This strain produced acetate, ethanol, $\mathrm{H}_{2}$, and $\mathrm{CO}_{2}$ from glucose metabolism. Fructose, xylose, ribose, cellobiose, and starch were also oxidized. The optimum temperature for growth was $60^{\circ} \mathrm{C}$. No growth was obtained at 42 or $70^{\circ} \mathrm{C}$. Strain $\mathrm{H168}$ grew optimally in $\mathrm{NaCl}$ concentrations ranging from 50 to $100 \mathrm{~g}$ per liter, with the upper and lower limits of growth around 200 and $40 \mathrm{~g}$ per liter, respectively. The $\mathrm{G}+\mathrm{C}$ ratio of the DNA was 39.6 mol\%. Although halophilic, moderately thermophilic bacteria have been characterized among anaerobes, particularly within methanogens, strain $\mathrm{H168}$ is the first true thermophilic (growing above $60^{\circ} \mathrm{C}$ ) halophilic anaerobic bacterium described so far. The phylogeny, physiology, morphology, lipid content, and high $\mathrm{G}+\mathrm{C}$ content of strain $\mathrm{H168}$ are sufficiently different from those of genera belonging to the family Haloanaerobiaceae to justify the definition of a new genus.
\end{abstract}

Extremophiles is a word coined to define microbes which live in extreme environments and includes thermophilic, halophilic, and alkalophilic members. All extremophiles are currently found among the domains Bacteria and Archaea $(28,32)$. Intensive research has been conducted on extremophilic microbes, with particular emphasis being placed on thermophilic microbes as this group of organisms has great commercial potential for thermostable enzymes $(9,14,33,34)$. Though a wide range of thermophilic physiological groups of bacteria is known to exist in the domain Bacteria, e.g., acidophiles, neutrophiles, aerobes, and anaerobes, very little is known about halophilic thermophiles. Indeed, the halophilic thermophilic bacteria studied so far are only slightly halophilic (haloduric) according to the scheme of Larsen $(4,5,10,16)$ as the optimum $\mathrm{NaCl}$ requirement for growth is less than $5 \%$. In the same domain, members of the family Haloanaerobiaceae are moderate halophiles $(22,40)$ but are not able to grow up to or above $60^{\circ} \mathrm{C}$ (17). The halophiles found in the domain Archaea are extreme halophiles but are not true thermophiles. Therefore, no true halophilic and thermophilic bacteria have been described so far.

We report in this paper the first moderate halophilic thermophile (most rapid growth between 5 and $17.5 \% \mathrm{NaCl}$ ) which ferments carbohydrates to acetate, ethanol, $\mathrm{H}_{2}$, and $\mathrm{CO}_{2}$.

(Part of this work was presented at the Annual Meeting of the American Society of Microbiology, Atlanta, Ga., 16 to 20 May 1993 [1]).

\section{MATERIALS AND METHODS}

Origin of strain. The occurrence of thermophilic halophilic anaerobic bacteria in the sediment of a Tunisian hypersaline lake (Chott El Guettar) was tested in samples collected at

\footnotetext{
* Corresponding author. Mailing address: Laboratoire de microbiologie, ORSTOM, Case 87, Université de Provence, 3 Pl. Victor Hugo, 13331 Marseille Cedex 03, France.
}

20 -cm intervals down to $1.20 \mathrm{~m}$. Strain $\mathrm{H} 168$ was present only in the $40-$ to $60-\mathrm{cm}$ layer. It was isolated at $60^{\circ} \mathrm{C}$ in a medium containing $100 \mathrm{~g}$ of $\mathrm{NaCl}$ per liter (the culture medium is described immediately below).

Culture medium. Enrichment medium contained the following (in grams per liter): $\mathrm{NH}_{4} \mathrm{Cl}, 1.0 ; \mathrm{KH}_{2} \mathrm{PO}_{4}, 0.3 ; \mathrm{K}_{2} \mathrm{HPO}_{4}$, $0.3 ; \mathrm{MgCl}_{2} \cdot 6 \mathrm{H}_{2} \mathrm{O}, 2.0 ; \mathrm{CaCl}_{2} \cdot 2 \mathrm{H}_{2} \mathrm{O}, 0.2 ; \mathrm{KCl}, 4.0 ;$ $\mathrm{CH}_{3} \mathrm{COONa} \cdot 3 \mathrm{H}_{2} \mathrm{O}, 1.0$; glucose, $10.0 ; \mathrm{NaCl}, 100$; bio-Trypcase (bioMérieux), 3.0; yeast extract (Difco), 3.0; resazurin $(0.1 \%$ [wt/vol] $), 1 \mathrm{ml}$; trace element solution ( 7$), 1 \mathrm{ml}$.

The $\mathrm{pH}$ of the medium was adjusted to 7.0 with $10 \mathrm{M} \mathrm{KOH}$, boiled under a stream of $\mathrm{O}_{2}$-free $\mathrm{N}_{2}$, and cooled to room temperature. Portions $(20 \mathrm{ml})$ of medium were distributed into $60-\mathrm{ml}$ serum bottles that were closed with butyl rubber stoppers according to the Hungate anaerobic technique (6). The serum bottles were gassed with $\mathrm{N}_{2}-\mathrm{CO}_{2}(80 \%-20 \%)$ and sterilized for $45 \mathrm{~min}$ at $110^{\circ} \mathrm{C}$. After sterilization, $0.2 \mathrm{ml}$ of $2 \%$ $\mathrm{Na}_{2} \mathrm{~S} \cdot 9 \mathrm{H}_{2} \mathrm{O}, 1 \mathrm{ml}$ of $10 \% \mathrm{NaHCO}_{3}$ (sterile, anaerobic solutions), and $0.1 \mathrm{ml}$ of a $0.2 \%$ sodium dithionite solution (filter-sterilized solution) were injected into the bottles. For preparing roll tubes, $2 \%$ agar (Difco) was added to the medium, and $5-\mathrm{ml}$ portions of medium were distributed into Hungate tubes as described above.

Depending on the experiments, various concentrations of yeast extract and bio-Trypcase were used. These concentrations will be mentioned when necessary.

Isolation procedure. Pure cultures were obtained by repeated application of the agar shake dilution method in anaerobic Hungate tubes as described previously (18). Purity was checked by lack of growth in a complex rich $\mathrm{NaCl}$-free medium at mesophilic and thermophilic temperatures.

Analytical techniques. Volatile fatty acids and alcohols were measured with a Delsi series 30 gas chromatograph, using an SP 1000 column with $1 \% \mathrm{H}_{3} \mathrm{PO}_{4}$ on Chromosorb WAW operating at $150^{\circ} \mathrm{C}$ with nitrogen as carrier gas. A flame ionization detector and a Delsi integrator were used.

Hydrogen and carbon dioxide were analyzed with a Girdel 


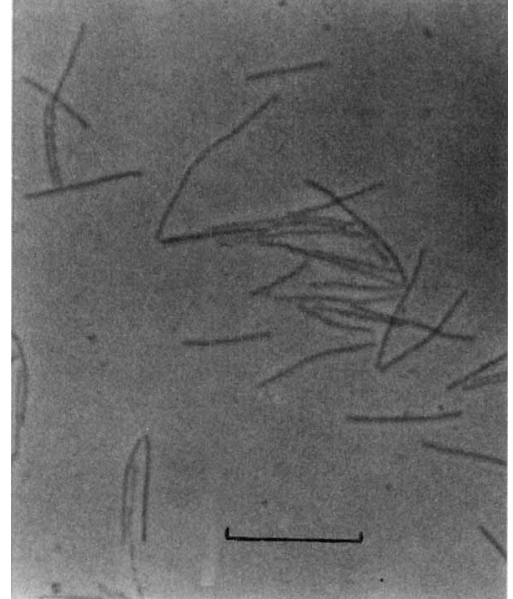

FIG. 1. Phase-contrast photomicrograph of strain H168. Bar $=10$ $\mu \mathrm{m}$.

series 30 gas chromatograph equipped with a thermal conductivity detector. The column was filled with Carbosphere SS $60 / 80$ mesh.

Glucose, lactate, and formate were assayed on diluted samples by high-performance liquid chromatography with an Analprep 93 pump (Touzart et Matignon, Vitry sur Seine, France) and an ORH 801 column (Interaction Chemicals, Inc., Mountain View, Calif.). The flow rate was $0.6 \mathrm{ml} \mathrm{min}{ }^{-1}$; the volume of the injection loop was $20 \mu \mathrm{l}$; the column temperature was $35^{\circ} \mathrm{C}$; the detector was a differential refractometer (Knauer, Berlin, Germany). Bacterial growth was quantified with a Shimadzu UV 160A spectrophotometer by measuring the increase in turbidity at $660 \mathrm{~nm}$ in the anaerobic Hungate tubes. All experiments were duplicated.

Lipid analysis. Lipid extraction, fatty acid purification, and quantification by capillary gas chromatography were performed as previously described (29). Briefly, a modified BlighDyer chloroform-methanol lipid extraction method was used. The total extractable lipids were fractionated by silicic-column chromatography. The fatty acid esters linked to the phospholipids were methylated by mild alkaline methanolysis, and the resulting fatty acid methyl esters were purified by thin-layer chromatography before gas chromatography analysis.

Lipid nomenclature. A shorthand nomenclature in the form of numbers separated by a colon was used. The number before the colon indicated the carbon chain length, and the number after the colon corresponded to the number of double bonds. The prefixes " $i$ " and "a" referred to iso- and anteiso-, respectively. If necessary, the geometry of the double bonds was indicated by cis and trans.

Electron microscopy. Cells were negatively stained with $4 \%$ (wt/vol) uranyl acetate in distilled water. Cells from an exponentially growing culture were fixed for $1 \mathrm{~h}$ in $0.07 \mathrm{M}$ sodium cacodylate buffer ( $\mathrm{pH} 7.3$ ) containing $1.2 \%$ glutaraldehyde and $0.05 \%$ ruthenium red. After the samples were washed in cacodylate buffer containing ruthenium red $(0.05 \%)$, they were fixed in $1 \%$ (wt/vol) $\mathrm{OsO}_{4}$ in $0.07 \mathrm{M}$ cacodylate buffer. The samples were embedded in Epon, and ultrathin sections were stained with $2 \%$ uranyl acetate in $50 \%$ ethanol and then with lead citrate. Micrographs were taken with a JEOL $1200 \mathrm{CX}$ electron microscope.

DNA base composition. The moles percent $\mathrm{G}+\mathrm{C}$ of the DNA was determined by DSM, Braunschweig, Germany. The DNA was isolated and purified by chromatography on hy-

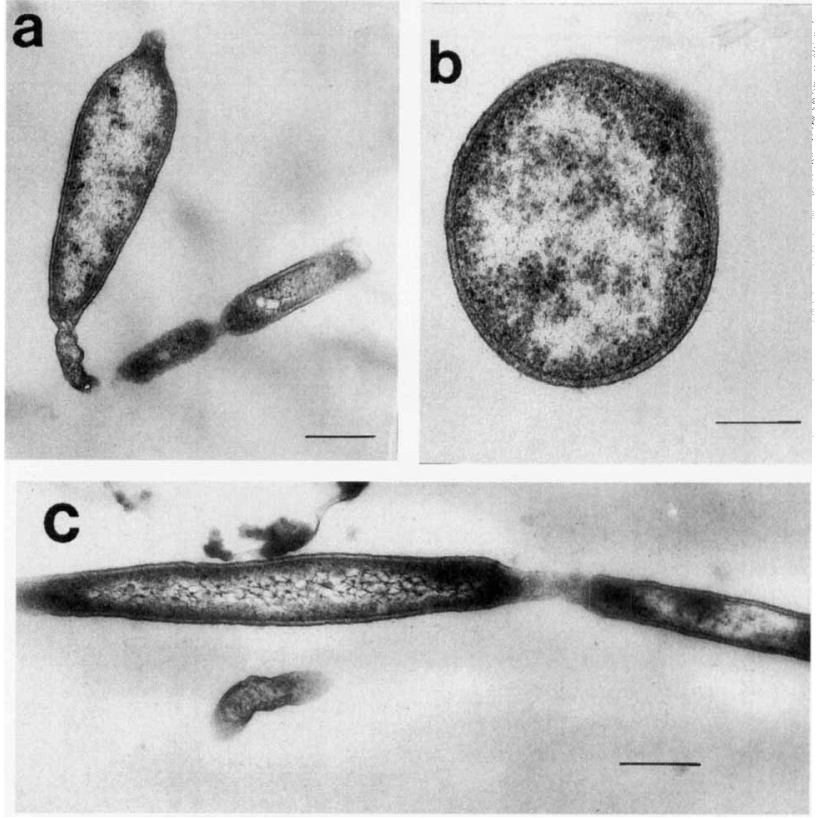

FIG. 2. Electron micrograph of fine section of strain H168. (a) Cytoplasmic deformation. Bar $=0.2 \mu \mathrm{m}$. (b) Typical gram-negative cell wall. Bar $=0.3 \mu \mathrm{m}$. (c) Irregularities in the diameter of cells. Bar $=0.2 \mu \mathrm{m}$.

droxyapatite. The $\mathrm{G}+\mathrm{C}$ content was determined by using high-performance liquid chromatography according to the method of Mesbah et al. (15). Nonmethylated lambda DNA (Sigma) served as the standard.

Phylogenetic analysis. The 16S rRNA gene was amplified from whole cells. For this, $1 \mathrm{ml}$ of the culture was centrifuged and resuspended in $50 \mu \mathrm{l}$ of sterile distilled water. A $4-\mu 1$ aliquot was removed and added to a tube containing $10 \mu \mathrm{l}$ of $10 \times$ Taq buffer $(500 \mathrm{mM} \mathrm{KCl}, 100 \mathrm{mM}$ Tris- $\mathrm{HCl}$ [pH 8.8], 15 $\mathrm{mM} \mathrm{MgCl} 2,1 \%$ Triton X-100). Fifty moles of a purified primer (designed against the conserved regions of the eubacterial 16S rRNA gene) pair was used: $5^{\prime}$ ccgaattcgtcgacaacAGAGTTT GATCCTGGCTCAG 3' (positions 8 to 27 forward, Escherichia coli numbering) and $5^{\prime}$ cccgggatccaagcttAAGGAGGT GATCCAGCC 3' (positions 1542 to 1526 reverse, E. coli numbering), where lowercase letters indicate the polylinker and the underlined regions indicate restriction enzyme sites of SalI and BamHI, respectively, which are useful in cloning. Portions (0.2 mM each) of dATP, dGTP, dCTP, and dTTP were added, and the mixture was made to a total of $98 \mu \mathrm{l}$ with sterile distilled water and overlaid with $90 \mu \mathrm{l}$ of light mineral oil (Sigma). The samples were placed in a Corbett thermal cycler, the cells were lysed, the released DNA was denatured at $95^{\circ} \mathrm{C}$ for $15 \mathrm{~min}$ and cooled to $50^{\circ} \mathrm{C}$, and then $2 \mathrm{U}$ of Taq DNA polymerase (Promega) was added. The samples were returned to the heating block of the thermal cycler where they were cycled through 32 cycles at $55^{\circ} \mathrm{C}$ for $1 \mathrm{~min}, 72^{\circ} \mathrm{C}$ for $4 \mathrm{~min}$, and $95^{\circ} \mathrm{C}$ for $1 \mathrm{~min}$, followed by a final cycle at $72^{\circ} \mathrm{C}$ for $20 \mathrm{~min}$ to ensure that all PCR products were completely extended.

The amplified product was purified, cloned, and sequenced essentially as described previously $(13,26)$. The sequence was aligned to various members of the domain Bacteria with the sequencing editor ae2, developed for the Ribosomal Database Project (20). The $16 \mathrm{~S}$ rRNA sequences used for comparison were extracted from the ribosomal data base of Olsen et al. (20) (version 2), and the sequence for Acidaminococcus fer- 
TABLE 1. 16S rRNA sequence matrix for various gram-positive bacteria and $H$. orenii ${ }^{a}$

\begin{tabular}{|c|c|c|c|c|c|c|c|c|c|c|c|c|}
\hline \multirow[b]{2}{*}{ Taxon } & \multicolumn{12}{|c|}{$\%$ Sequence similarity to: } \\
\hline & 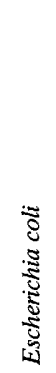 & 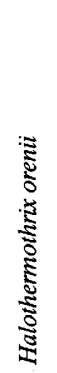 & 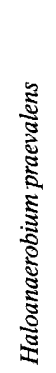 & 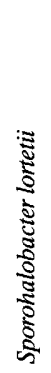 & 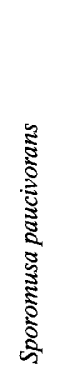 & 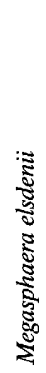 & 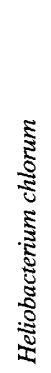 & 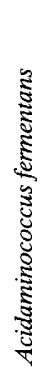 & 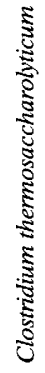 & 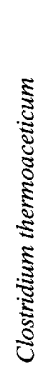 & 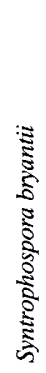 & 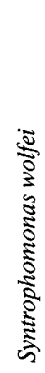 \\
\hline
\end{tabular}

Escherichia coli

Halothermothrix orenii

Haloanaerobium praevalens

Sporohalobacter lortetii

Sporomusa paucivorans

Megasphaera elsdenii

Heliobacterium chlorum

Acidaminococcus fermentans

Clostridium thermosaccharolyticum

Clostridium thermoaceticum

Syntrophospora bryantii

Syntrophomonas wolfei
74.2

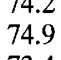

73.4

73.8

76.8

79.3

73.1

76.2

77.7

76.5

71.9

$$
\begin{aligned}
& 80.0 \\
& 78.6 \\
& 73.2 \\
& 74.0 \\
& 78.3 \\
& 73.6 \\
& 75.4 \\
& 77.4 \\
& 75.4 \\
& 71.3
\end{aligned}
$$

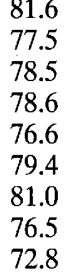

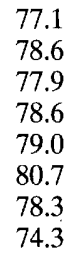

\section{5}

81.0
87.0

87.0

77.8

81.3

81.6

77.3

81.3
82.8
80.5
82.8
79.4
75.2

\section{8}

81.0

83.9

82.4

76.3
77.8
80.3
80.5
77.7

\section{6}

80.4

76.1
93.7

79.7
87.4

${ }^{a}$ Sequences used in the analysis are from the Ribosomal Database Project (version 2 [20]), and an additional 16S rRNA sequence of $A$. fermentans was obtained from GenBank (accession no. X65935). The sequence of the 16S rRNA gene of $H$. orenii has been deposited in GenBank (accession number L22016). A total of 1,106 unambiguous nucleotides were used for analysis by the Jukes and Cantor method (8) as modified by Olsen (19).

mentans (accession no. X65935) was extracted from GenBank (release 76). Positions of sequence and alignment uncertainties were omitted from the analysis, and 1,106 nucleotides were used in the analysis.

Pairwise evolutionary distances were computed from percent similarities by the distance correction method of Jukes and Cantor (8) described by Olsen (19). Phylogenetic trees of topology were constructed from evolutionary distances by using the algorithm of De Soete (2). PHYLIP (version 3.51c) was used to reexamine tree topology (3). Distance similarity matrices were computed by the Jukes and Cantor method (8) from multiple data sets (100 sets) produced with the SEQ BOOT program. The 100 distance matrices were computed as evolutionary distances by using the program FITCH, and the program CONSENSE was used to generate a consensus tree.

Nucleotide sequence accession number. The sequence of the amplified and cloned 16S rRNA gene has been deposited in GenBank under the accession number L22016.

\section{RESULTS}

Enrichment and isolation. A sediment suspension from each $20-\mathrm{cm}$ layer from Chott El Guettar was inoculated into enrichment medium containing glucose and $100 \mathrm{~g}$ of $\mathrm{NaCl}$ per liter and incubated at $55^{\circ} \mathrm{C}$. When growth was observed, the bacterial enrichments were further subcultured and incubated at $60^{\circ} \mathrm{C}$. Although bacterial growth was observed with suspensions of the different layers at $55^{\circ} \mathrm{C}$, growth was observed only with the $40-$ to $60-\mathrm{cm}$ layer enrichment at $60^{\circ} \mathrm{C}$. This sample was serially diluted in agar roll tubes, and several identical morphological colonies from the highest positive dilution were picked up with a sterile Pasteur pipet and rediluted into another agar dilution series. This process was repeated until pure cultures were obtained. Strain $\mathrm{H} 168$ was chosen for further characterization.
Colony and morphological characteristics. Colonies were yellow, flat, and circular with diameters ranging from 0.5 to 1.0 $\mathrm{mm}$, depending on the incubation time.

Cells were long, flexible rods occurring mainly singly (10 to 20 by 0.4 to $0.6 \mu \mathrm{m}$ ) (Fig. 1) and presenting a cytoplasmic concentration with deformation of the membrane (Fig. 2a). The cell wall was typical of gram-negative bacteria (Fig. 2b). Irregularities in the diameter of cells were observed (Fig. 2c). Strain H168 had peritrichous flagella (data not shown).

Growth conditions. Strain H168 was an obligate anaerobe and a moderate halophile, with yeast extract being required for growth. It grew optimally at $\mathrm{NaCl}$ concentrations ranging from 50 to $100 \mathrm{~g}$ per liter; the upper and lower limits of growth were around 200 and $40 \mathrm{~g}$ of $\mathrm{NaCl}$ per liter. Strain $\mathrm{H} 168$ did not require $\mathrm{MgCl}_{2}$ but tolerated it up to $0.7 \mathrm{M}$ when $100 \mathrm{~g}$ of $\mathrm{NaCl}$ per liter was present in the medium. The optimal growth temperature was $60^{\circ} \mathrm{C}$; growth occurred between 45 and $68^{\circ} \mathrm{C}$ but not at $70^{\circ} \mathrm{C}$. No growth was observed above $\mathrm{pH} 8.2$ or below pH 5.5, with an optimal range between $\mathrm{pH} 6.5$ and 7.0. The following compounds served as energy sources: arabinose, cellobiose, fructose, galactose, glucose, mannose, melibiose, ribose, starch, and xylose. No growth was observed on lactose, maltose, rhamnose, sucrose, sorbose, cellulose, formate, acetate, butyrate, propionate, fumarate, lactate, malate, succinate, adonitol, dulcitol, glycerol, mannitol, Casamino Acids, bioTrypcase, and trimethylamine. Products of glucose fermentation were ethanol, acetate, $\mathrm{H}_{2}$, and $\mathrm{CO}_{2}$.

$\mathbf{G}+\mathbf{C}$ content. The average DNA base composition of strain $\mathrm{H} 168$ was $39.6 \mathrm{~mol} \% \mathrm{G}+\mathrm{C}$.

Phylogeny. Using 12 primers, a nearly complete sequence consisting of 1,482 bases (96\%) of the amplified and cloned 16S rRNA gene of strain H168 was determined. Some 60 bases from the $5^{\prime}$ end could not be determined since there was a SalI restriction site at position $68(E$. coli numbering according to Winkler and Woese [30]) and therefore these bases had been 


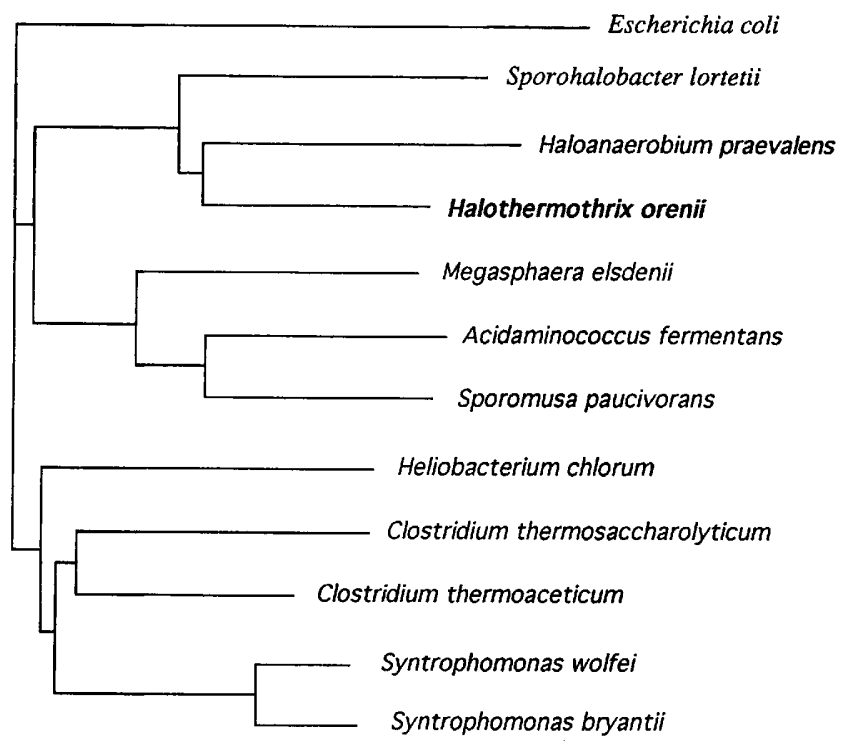

$10 \%$

FIG. 3. An unrooted phylogenetic tree showing the relationship of $H$. orenii to other members of the gram-positive branch. The tree was derived from the sequence similarity matrix of Jukes and Cantor as implemented by Olsen (19) (Table 1) by the method of de Soete (2).

restriction enzyme digested prior to the cloning process. The sequence had 62 signatures, which indicated that it was a member of the domain Bacteria (30). Additional signatures indicated that it was a member of the gram-positive line of descent (31). The sequence of strain H168 was therefore aligned and compared to the $16 \mathrm{~S}$ rRNAs of various characterized gram-positive bacteria (Table 1). Several phylogenetic trees were generated by changing the composition of reference organisms. All the trees generated were comparable, and a tree generated by using the algorithm of De Soete (2) is shown in Fig. 3. The strain H168 sequence was more closely related to those of two halophilic anaerobic bacteria whose 16S rRNA sequences have been determined, viz., Haloanaerobium praevalens and Sporohalobacter lortetii ( 80 and $81.6 \%$, respectively). A signature region of 22 nucleotides (positions 821 to 842 ) with the sequence GGAUACUAGGUGUUGGRGGUUC, which differentiates the three halophilic anaerobes from all other gram-positive bacteria, has been identified. In addition, a unique shortened secondary structural variant in part of helix 47 (positions 1435 to 1466 ) which is common to all three halophilic anaerobes but not present in any of the other gram-positive bacteria has been identified (Fig. 4).

Bootstrap analysis has indicated that the relationship of strain $\mathrm{H} 168$ to Haloanaerobium praevalens is not robust (76\%), but the relationship of strain $\mathrm{H} 168$ and Haloanaerobium praevalens to $S$. lortetii is very stable $(100 \%)$. 16S rRNA sequence analysis of more halophilic anaerobes may assist in stabilizing the branch.

Lipid analysis. The phospholipid fatty acid profile is listed in Table 2. This profile is characterized by the absence of unsaturated fatty acids. Branched chain saturates account for $75 \%$ of the total fatty acids, with i15:0 fatty acid predominating.

$$
\begin{gathered}
U^{G}{ }^{G} \\
C-G \\
C-G \\
A-U \\
C-G \\
U \circ C \\
G-C \\
5
\end{gathered}
$$

(a)

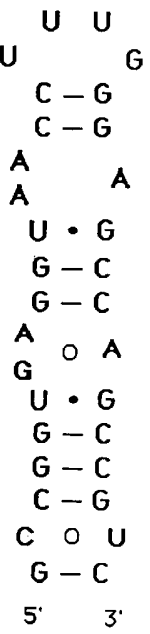

(d)

$$
\begin{gathered}
U^{G}{ }^{C} \\
C-G \\
U-A \\
A-U \\
C-G \\
U O C \\
\text { G }-C \\
5.3
\end{gathered}
$$

(b)

$$
\begin{gathered}
A C \\
C-G \\
C-G \\
G-C \\
C-G \\
U \circ C \\
G-C \\
5
\end{gathered}
$$

\begin{tabular}{|c|c|}
\hline Fatty acid & $\begin{array}{c}\% \text { of fatty } \\
\text { acids }\end{array}$ \\
\hline (1) & 2.29 \\
\hline i14:0 & 1.54 \\
\hline $14: 0$ & 7.96 \\
\hline 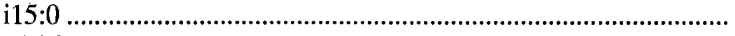 & 54.3 \\
\hline (1) & 9.79 \\
\hline 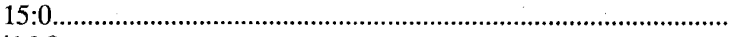 & 1.57 \\
\hline 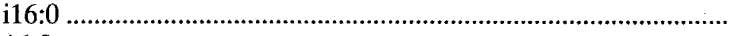 & 2.68 \\
\hline 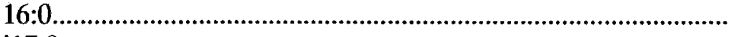 & 9.94 \\
\hline i17:0 . & 4.99 \\
\hline a17:0 & 2.34 \\
\hline 17:0, & 0.35 \\
\hline i18:0 & 0.20 \\
\hline 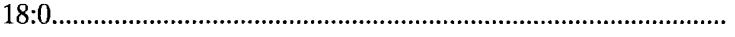 & 1.22 \\
\hline Total & 99.07 \\
\hline 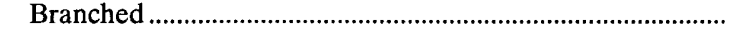 & 75.64 \\
\hline
\end{tabular}

(c)

$$
\begin{aligned}
& \text { U C } \\
& \text { U G } \\
& C-G \\
& \text { C }-\mathbf{G} \\
& \text { A } A \\
& \text { U } \cdot \mathbf{G} \\
& \text { U. G } \\
& C-G \\
& G-C \\
& \text { A } \\
& \text { U } \cdot \mathbf{G} \\
& \text { G-C } \\
& \text { G - U } \\
& A-U \\
& U-A \\
& \text { G - C } \\
& 5.3
\end{aligned}
$$

(e)

FIG. 4. Secondary structure of halophilic anaerobes, showing the common shortened structure of a part of helix 47 consisting of 16 nucleotides in $H$. orenii (a), Halobacteroides praevalens (b), and $S$. lortetii (c) compared with those of other gram-positive members which consist of more than 32 nucleotides; the structure of $M$. elsdenii (d) is shown as an example. The corresponding region of helix 47 in $E$. coli (positions 1435 to 1466) (e) is shown for comparison.

\section{DISCUSSION}

Research on hypersaline ecosystems has led to the description of the family Haloanaerobiaceae $(22,23)$, which now includes six genera and nine species $(12,21,24,25,27,35-37$, 39,40 ) (Table 3 ). The family consists of exclusively mesophilic

TABLE 2. Fatty acid profile of strain $\mathrm{H} 168$ 
TABLE 3. Characteristics of the species of the family Haloanaerobiaceae

\begin{tabular}{|c|c|c|c|c|c|c|c|c|c|}
\hline \multirow[b]{2}{*}{ Species (reference[s]) } & \multirow[b]{2}{*}{ Morphology } & \multirow[b]{2}{*}{ Size $(\mu \mathrm{m})$} & \multirow[b]{2}{*}{$\underset{\text { stain }}{\text { Gram }}$} & \multirow[b]{2}{*}{ Spores } & \multirow[b]{2}{*}{ Motility } & \multicolumn{2}{|c|}{$\% \mathrm{NaCl}$} & \multirow[b]{2}{*}{$\begin{array}{c}\text { Temp }\left({ }^{\circ} \mathrm{C}\right) \\
\text { range }\end{array}$} & \multirow[b]{2}{*}{$\underset{\text { range }}{\mathrm{pH}}$} \\
\hline & & & & & & Range & Optimum & & \\
\hline Halothermothrix orenii & Rods & $0.4-0.6$ by $10-20$ & Negative & - & + & $4-20$ & $5-10$ & $42-70$ & $5.5-8.2$ \\
\hline Halobacteroides halobius MD-1 (25) & Flexible rods & 0.5 by $10-20$ & Negative & + & + & $8-17$ & 9-14 & $37-42$ & ND \\
\hline Halobacteroides halobius Z-7287 (36) & Flexible rods & $0.3-0.5$ by $2-20$ & Negative & $t^{b}$ & + & $8-30$ & $9-15$ & $30-47$ & ND \\
\hline Halobacteroides acetoethylicus (27) & Rods & $0.4-0.7$ by $1-1.6$ & Negative & - & + & $6-20$ & 10 & $15-45$ & $5.4-8.0$ \\
\hline Halobacteroides lacunaris (37) & Flexible rods & $0.7-1$ by $0.5-6$ & Negative & - & + & $5-30$ & $15-18$ & $25-52$ & $6.0-8.0$ \\
\hline Haloanaerobium praevalens (35) & Rods & 0.5 by 1.5 & Negative & - & - & $2-30$ & 12.5 & $15-50$ & $6.0-8.0$ \\
\hline Haloanaerobacter chitinovorans (12) & Rods & 0.5 by $1.4-8$ & Negative & - & + & $3-30$ & $12-18$ & $25-50$ & ND \\
\hline Sporohalobacter lortetii $(21,24)$ & Rods & $0.5-0.6$ by $2.5-10$ & Negative & + & + & $4-15$ & $8-9$ & $25-52$ & ND \\
\hline Sporohalobacter marismortui (24) & Rods & 0.6 by $3-13$ & Negative & + & + & 3-18 & $3-12$ & $25-50$ & ND \\
\hline Acetohalobium arabaticum (39) & Curved rods & $0.7-1$ by $2-5$ & Negative & $t^{b}$ & + & $10-25$ & $15-18$ & ND-47 & $5.6-8.4$ \\
\hline Haloincola saccharolytica (40) & Rods & $0.5-0.7$ by $1-1.5$ & Negative & - & + & $3-30$ & 10 & $15-47$ & $6.0-8.0$ \\
\hline
\end{tabular}

${ }^{a} \mathrm{ND}$, not determined.

${ }^{b}$ Oligospores.

${ }^{c} \pm$, poorly used.

${ }^{d}$ In rich medium, sugar is poorly used.

${ }^{e}$ From betaine degradation.

bacteria with the exception of Halobacteroides lacunaris, a moderately thermophilic bacterium with an upper temperature limit of $52^{\circ} \mathrm{C}$ (37). Our report on strain $\mathrm{H} 168$, isolated from a hypersaline Tunisian lake (Chott El Guettar), extends the temperature limit of halophilic anaerobic bacteria to $68^{\circ} \mathrm{C}$ for the first time. Similarly, the optimum temperature for growth of strain $\mathrm{H} 168$ is $60^{\circ} \mathrm{C}$, higher than that of any moderate halophilic microbe reported to date, including that of the extremely halophilic thermophilic archaean Methanohalobium evestigatum (38).

The phospholipid fatty acid profile of strain H168 contains a preponderance of branched saturated fatty acids $(75.6 \%)$ of which i- and a15:0 and 16:0 dominate. This is a trait commonly found among genuine thermophilic bacteria because of growth at high temperatures. Strain H168 is a thermophile, but its obligate salt requirement and lower optimum growth temperature $\left(60^{\circ} \mathrm{C}\right)$ indicate that it is unrelated to other thermophilic bacteria, e.g., Thermoanaerobacter spp. (11). Similarly, the lack of lactate production from glucose by strain $\mathrm{H} 168$ also rules out any similarity with other thermophilic bacteria, as all of the latter produce lactate.

Strain H168 is a rod-shaped anaerobic and halophilic bacterium and therefore resembles members of the family Haloanaerobiaceae. However, there are considerable biochemical and physiological differences between strain H168 and validly published and approved members of the family Haloanaerobiaceae (Table 3). This relationship is further strengthened by phylogenetic analysis of $16 \mathrm{~S}$ rRNA. The presence of a common stretch of sequence at positions 821 to 842 and of a common shortened secondary structural variant in part of helix 47 at positions 1435 to 1466 also supports this analysis. However, strain H168 produces acetate and ethanol as the major end products of glucose fermentation and hence resembles Halobacteroides species. Because data on the phylogenetic positions of the members of Halobacteroides are not available for comparison, it could be argued that it is a species of Halobacteroides. However, numerous differences in the physiological and biochemical characteristics do not support this contention. The main difference is the higher $\mathrm{G}+\mathrm{C}$ content of strain H168 (39.6\%) than of Halobacteroides species (30.7 to $32.4 \%$ ) along with the higher growth temperature and nutritional profiles. Strain $\mathrm{H} 168$ differed from Halobacteroides halobius in using ribose, xylose, and cellobiose but not oxidizing maltose and sucrose. In contrast to Halobacteroides acetoethylicus, strain H168 oxidized galactose and starch but not sucrose or lactose. Finally, Halobacteroides lacunaris uses a significantly different range of substrates, including maltose, mannitol, sucrose, and sorbose.

On the basis of the evidence presented in this paper, we propose to place strain $\mathrm{H} 168$ as the type strain of a new genus Halothermothrix gen. nov., in the species Halothermothrix orenii sp. nov,

Description of the genus Halothermothrix gen. nov. Halothermothrix (Ha.lo.ther.mo'thrix Gr. n. hal, salt; Gr. adj. thermus, heat; Gr. n. thrix, hair; M.L. fem. m. Halothermothrix, a thermophilic fermentative halophile). Rod-shaped eubacterium with cells that are 0.4 to 0.6 by 10 to $20 \mu \mathrm{m}$ and occur mainly singly. Motile by peritrichous flagella. Spores are not formed. Gram negative. Chemoorganotrophic, strictly anaerobic, and obligately halophilic. The $\mathrm{G}+\mathrm{C}$ content of the DNA is $39.6 \%$. Does not possess unsaturated fatty acid in the lipid cell wall composition but contains a preponderance of saturated fatty acids, a reflection of its thermophilic nature. Phylogenetically, the genus is a member of the Haloanaerobiaceae family and is contained within the low-GC-containing subdivision of the gram-positive branch.

Description of Halothermothrix orenii sp. nov. Halothermothrix orenii (o.ren'i.i M.L. gen. n. orenii, of Oren, name in honor of Aharon Oren, who made important contributions to the knowledge of halophilic anaerobic bacteria). In addition to the characteristics given in the description above, $H$. orenii has the characteristics described below. Colonies are yellow, flat, and circular with 0.5 - to $1-\mathrm{mm}$ diameters. Chemoorganotrophic and strictly anaerobic. Oxidizes carbohydrates including arabinose, cellobiose, fructose, galactose, glucose, melibiose, mannose, starch, ribose, and xylose but not lactose, maltose, rhamnose, sucrose, sorbose, cellulose, formate, acetate, butyrate, propionate, fumarate, lactate, malate, succinate, adonitol, dulcitol, glycerol, mannitol, Casamino Acids, bio-Trypcase, or trimethylamine. The end products of fermentation are acetate, ethanol, $\mathrm{H}_{2}$, and $\mathrm{CO}_{2} . \mathrm{NaCl}$ and yeast extract are required for growth. The optimum $\mathrm{NaCl}$ concentration for growth is about $10 \%$, with upper and lower limits of 20 and $4 \%$, respectively. The $\mathrm{pH}$ range for growth is 5.5 to 8.2 ; the 
TABLE 3-Continued

\begin{tabular}{|c|c|c|c|c|c|c|c|c|c|}
\hline \multirow[b]{2}{*}{$\begin{array}{l}\text { Doubling } \\
\text { time (h) }\end{array}$} & \multirow[b]{2}{*}{ Habitat } & \multirow[b]{2}{*}{$\begin{array}{c}\mathrm{G}+\mathrm{C} \\
(\mathrm{mol} \%)\end{array}$} & \multicolumn{6}{|c|}{ Substrates used } & \multirow[b]{2}{*}{ End products from glucose } \\
\hline & & & $\begin{array}{l}\text { Carbo- } \\
\text { hydrates }\end{array}$ & $\begin{array}{l}\text { Amino } \\
\text { acids }\end{array}$ & $\begin{array}{l}N \text {-Acetyl- } \\
\text { glucos- } \\
\text { amine }\end{array}$ & Starch & Chitin & Cellulose & \\
\hline 5.3 & Chott El Guettar & 39.6 & + & - & $\mathrm{ND}^{a}$ & + & ND & - & Acetate, ethanol, $\mathrm{H}_{2}, \mathrm{CO}_{2}$ \\
\hline 8 & Dead Sea & 30.7 & + & - & - & + & ND & ND & Acetate, ethanol, $\mathrm{H}_{2}, \mathrm{CO}_{2}$ \\
\hline $1-2$ & Dead Sea-Lake Sivash & 30.7 & + & - & - & + & ND & ND & Acetate, ethanol, $\mathrm{H}_{2}, \mathrm{CO}_{2}$ \\
\hline 7.8 & Oil well & 32.0 & + & - & + & - & - & ND & Acetate, ethanol, $\mathrm{H}_{2}, \mathrm{CO}_{2}$ \\
\hline 2.9 & Lake Chokrak & 32.4 & + & - & - & + & - & ND & Acetate, ethanol, $\mathrm{H}_{2}, \mathrm{CO}_{2}$ \\
\hline 4 & Great Salt Lake & 27.0 & + & + & + & - & - & ND & Acetate, butyrate, propionate, $\mathrm{H}_{2}, \mathrm{CO}_{2}$ \\
\hline 2.5 & Solar saltern & 34.8 & + & ND & + & $\pm^{c}$ & + & - & Acetate, isobutyrate, $\mathrm{H}_{2}, \mathrm{CO}_{2}$ \\
\hline 8 & Dead Sea & 31.5 & + & ND & ND & + & ND & ND & $\begin{array}{l}\text { Acetate }{ }^{d} \text {, propionate, isobutyrate, butyrate, } \\
\text { isovalerate, } \mathrm{H}_{2}\end{array}$ \\
\hline ND & Dead Sea & 29.6 & + & - & ND & + & - & ND & Acetate, ethanol, butyrate, formate, $\mathrm{H}_{2}, \mathrm{CO}_{2}$ \\
\hline ND & Lake Sivash & 33.6 & - & + & ND & ND & ND & ND & Acetate $^{e}$, trimethylamine $e^{e}$ \\
\hline 3.9 & Lake Sivash & 31.3 & + & - & + & ND & - & ND & Acetate, $\mathrm{H}_{2}, \mathrm{CO}_{2}$ \\
\hline
\end{tabular}

optimum $\mathrm{pH}$ is 6.5 to 7.0 . Grows between 45 and $68^{\circ} \mathrm{C}$, with no growth occurring at $70^{\circ} \mathrm{C}$. The optimum temperature for growth is $60^{\circ} \mathrm{C}$. Isolated from sediments of a Tunisian salted lake (Chott El Guettar) from a depth of 40 to $60 \mathrm{~cm}$ but not from any other depth (up to $1.2 \mathrm{~m}$ ). The type strain is strain $\mathrm{H} 168$, deposited in the Oregon Collection of Methanogens (OCM 544).

\section{ACKNOWLEDGMENTS}

We are indebted to J. L. Job, R. Pontanier, and B. Dalmayrac for sampling the sediment in Tunisia.

This research was supported in part by a grant from Elf Aquitaine (J.L.C.) and the Australian Research Council (B.K.C.P.).

\section{REFERENCES}

1. Cayol, J.-L., B. Ollivier, G. Prensier, J. Guezennec, B. Patel, and J.-L. Garcia. 1993. Isolation of a thermophilic anaerobic halophilic fermentative bacterium from a Tunisian chott, abstr. I-88, p. 255. Abstr. 93rd Annu. Meet. Am. Soc. Microbiol. 1993. American Society for Microbiology, Washington, D.C.

2. De Soete, G. 1983. A least square algorithm for fitting additive trees to proximity data. Psychometrika 48:621-626.

3. Felsenstein, J. 1993. PHYLIP (Phylogeny Inference Package) version 3.51c. Distributed by the author, Department of Genetics, University of Washington, Seattle.

4. Huber, R., T. A. Langworthy, H. König, M. Thomm, C. R. Woese, U. B. Sleytr, and K. O. Stetter. 1986. Thermotoga maritima sp. nov. represents a new genus of unique extremely thermophilic eubacteria growing up to $90^{\circ} \mathrm{C}$. Arch. Microbiol. 144:324-333.

5. Huber, R., C. R. Woese, T. A. Langworthy, H. Fricke, and K. $O$. Stetter. 1989. Thermosipho africanus gen. nov. represents a new genus of thermophilic eubacteria within the "Thermotogales." Syst. Appl. Microbiol. 12:32-37.

6. Hungate, R. E. 1969. A roll-tube method for the cultivation of strict anaerobes, p. 117-132. In J. R. Norris and D. W. Ribbons (ed.), Methods in microbiology, vol. 3B. Academic Press, New York.

7. Imhoff-Stuckle, D., and N. Pfennig. 1983. Isolation and characterization of a nicotinic acid-degrading sulfate-reducing bacterium, Desulfococcus niacini sp. nov. Arch. Microbiol. 136:194-198.

8. Jukes, T. H., and C. R. Cantor. 1969. Evolution of protein molecules, p. 21-132. In H. N. Munro (ed.), Mammalian protein metabolism. Academic Press, New York.

9. Klingeberg, M., F. Hashwa, and G. Antranikian. 1991. Properties of extremely thermostable proteases from anaerobic hyperthermophilic bacteria. Appl. Microbiol. Biotechnol. 34:715-719.

10. Larsen, H. 1962. Halophilism, p. 297-342. In I. C. Gunsalus and R. C. Stanier (ed.), The bacteria: a treatise on structure and function, vol. 4. Academic Press, New York.

11. Lee, Y.-E., M. K. Jain, C. Lee, S. E. Lowe, and J. G. Zeikus. 1993.
Taxonomic distinction of saccharolytic thermophilic anaerobes: description of Thermoanaerobacterium xylanolyticum gen. nov., sp. nov., and Thermoanaerobacterium saccharolyticum gen. nov., sp. nov.; reclassification of Thermoanaerobium brockii, Clostridium thermosulfurogenes, and Clostridium thermohydrosulfuricum E10069 as Thermoanaerobacter brockii comb. nov., Thermoanaerobacterium thermosulfurogenes comb. nov., and Thermoanaerobacter thermohydrosulfuricus comb. nov., respectively; and transfer of Clostridium thermohydrosulfuricum $39 \mathrm{E}$ to Thermoanaerobacter ethanolicus. Int. J. Syst. Bacteriol. 43:41-51.

12. Liaw, H. J., and R. A. Mah. 1992. Isolation and characterization of Haloanaerobacter chitinovorans gen. nov., sp. nov., a halophilic, anaerobic, chitinolytic bacterium from a solar saltern. Appl. Environ. Microbiol. 58:260-266.

13. Love, C. A., B. K. C. Patel, P. D. Nichols, and E. Stackebrandt. 1993. Desulfotomaculum australicum sp. nov., a thermophilic sulfate-reducing bacterium isolated from the Great Artesian Basin of Australia. Syst. Appl. Microbiol. 16:244-251.

14. Lowe, S. E., M. K. Jain, and J. G. Zeikus. 1993. Biology, ecology, and biotechnological applications of anaerobic bacteria adapted to environmental stresses in temperature, $\mathrm{pH}$, salinity, or substrates. Microbiol. Rev. 57:451-509.

15. Mesbah, M., U. Premachandran, and W. B. Whitman. 1989. Precise measurement of the $\mathrm{G}+\mathrm{C}$ content of deoxyribonucleic acid by high-performance liquid chromatography. Int. J. Syst. Bacteriol. 39:159-167.

16. Nazina, T. N., A. E. Ivanova, L. P. Kanchaveli, and E. P. Rozanova. 1989. A new sporeforming thermophilic methylotrophic sulfatereducing bacterium, Desulfotomaculum kuznetsovii sp. nov. Mikrobiologiya 57:659-663.

17. Ollivier, B., P. Caumette, J.-L. Garcia, and R. A. Mah. 1994. Anaerobic bacteria from hypersaline ecosystems. Microbiol. Rev. 58:27-38.

18. Ollivier, B., C. E. Hatchikian, G. Prensier, J. Guezennec, and J.-L. Garcia. 1991. Desulfohalobium retbaense gen. nov., sp. nov., a halophilic sulfate-reducing bacterium from sediments of a hypersaline lake in Senegal. Int. J. Syst. Bacteriol. 41:74-81.

19. Olsen, G. J. 1988. Phylogenetic analysis using ribosomal RNA. Methods Enzymol. 164:793-812.

20. Olsen, G. J., R. Overbeek, N. Larsen, T. L. March, M. J. McCaughey, M. A. Maciukenas, W. M. Kuan, T. J. Macke, Y. Xing, and C. R. Woese. 1992. The Ribosomal Database Project. Nucleic Acids Res. 20:2199-2200.

21. Oren, A. 1983. Clostridium lortetii sp. nov., a halophilic obligatory anaerobic bacterium producing endospores with attached gas vacuoles. Arch. Microbiol. 136:42-48.

22. Oren, A. 1986. The ecology and taxonomy of anaerobic halophilic eubacteria. FEMS Microbiol. Rev. 39:23-29.

23. Oren, A., B. J. Paster, and C. R. Woese. 1984. Haloanaerobiaceae: a new family of moderately halophilic obligatory anaerobic bacteria. Syst. Appl. Microbiol. 5:71-80. 
24. Oren, A., H. Pohla, and E. Stackebrandt. 1987. Transfer of Clostridium lortetii to a new genus Sporohalobacter gen. nov. as Sporohalobacter lortetii comb. nov., and description of Sporohalobacter marismortui sp. nov. Syst. Appl. Microbiol. 9:239-246.

25. Oren, A., W. G. Weisburg, M. Kessel, and C. R. Woese. 1984. Halobacteroides halobius gen. nov., sp. nov., a moderately halophilic anaerobic bacterium from the bottom sediments of the Dead Sea. Syst. Appl. Microbiol. 5:58-70.

26. Redburn, A. C., and B. K. C. Patel. 1993. Phylogenetic analysis of Desulfotomaculum thermobenzoicum using polymerase chain reaction-amplified 16S rRNA-specific DNA. FEMS Microbiol. Lett. 113:81-86.

27. Rengpipat, S., T. A. Langworthy, and J. G. Zeikus. 1988. Halobacteroides acetoethylicus sp. nov., a new obligately anaerobic halophile isolated from deep subsurface hypersaline environments. Syst. Appl. Microbiol. 11:28-35.

28. Stetter, K. O., G. Fiala, G. Huber, R. Huber, and A. Segerer. 1990. Hyperthermophilic microorganisms. FEMS Microbiol. Rev. 75: $117-124$.

29. White, D. C., W. M. Davis, J. S. Nickels, J. D. King, and R. J. Bobbie. 1979. Determination of the sedimentary microbial biomass by extractable lipid phosphate. Oecologia (Berlin) 40:51-62.

30. Winkler, S., and C. R. Woese. 1991. A definition of the domains Archaea, Bacteria and Eucarya in terms of small subunit ribosomal RNA characteristics. Syst. Appl. Microbiol. 14:305-310.

31. Winter, J., and G. Zellner. 1990. Thermophilic anaerobic degradation of carbohydrates-metabolic properties of microorganisms from the different phases. FEMS Microbiol. Rev. 75:139-154.

32. Woese, C. R., O. Kandler, and M. L. Wheelis. 1990. Towards a natural system of organisms: proposal for the domains Archaea, Bacteria, and Eucarya. Proc. Natl. Acad. Sci. USA 87:4576-4579.
33. Zamost, B. L., H. K. Nielsen, and R. L. Starnes. 1991. Thermostable enzymes for industrial applications. J. Ind. Microbiol. 8: 71-82.

34. Zeikus, J. G. 1979. Thermophilic bacteria: ecology, physiology and technology. Enzyme Microb. Technol. 1:243-252.

35. Zeikus, J. G., P. W. Hegge, T. E. Thompson, T. J. Phelps, and T. A. Langworthy. 1983. Isolation and description of Haloanaerobium praevalens gen. nov. and sp. nov., an obligately anaerobic halophile common to Great Salt Lake sediments. Curr. Microbiol. 9:225234.

36. Zhilina, T. N., V. V. Kevbrin, A. M. Lysenko, and G. A. Zavarzin. 1991. Isolation of saccharolytic anaerobes from a halophilic cyanobacterial mat. Mikrobiologiya 60:101-107.

37. Zhilina, T. N., L. V. Miroshnikova, G. A. Osipov, and G. A. Zavarzin. 1991. Halobacteroides lacunaris sp. nov., new saccharolytic, anaerobic, extremely halophilic organism from the lagoonlike hypersaline lake Chokrak. Mikrobiologiya 60:495-503.

38. Zhilina, T. N., and G. A. Zavarzin. 1987. Methanohalobium evestigatum gen. nov., sp. nov., extremely halophilic methaneproducing archaebacteria. Dokl. Akad. Nauk SSSR 293:464-468. (In Russian.)

39. Zhilina, T. N., and G. A. Zavarzin. 1990. A new extremely halophilic homoacetogenic bacterium Acetohalobium arabaticum gen. nov., sp. nov. Dokl. Akad. Nauk SSSR 311:745-747. (In Russian.)

40. Zhilina, T. N., G. A. Zavarzin, E. S. Bulygina, V. V. Kevbrin, G. A. Osipov, and K. M. Chumakov. 1991. Ecology, physiology and taxonomy studies on a new taxon of Haloanaerobiaceae, Haloincola saccharolytica gen. nov., sp. nov. Syst. Appl. Microbiol. 15: 275-284. 